\title{
c-Kit Is Not Expressed in Malignant Mesothelioma
}

\author{
Andrew E. Horvai, M.D., Ph.D., Li Li, Ph.D., Zhidong Xu, Ph.D., Miranda J. Kramer, R.N., M.S., \\ David M. Jablons, M.D., Patrick A. Treseler, M.D., Ph.D. \\ Departments of Pathology (AEH, PAT) and Surgery (LL, SX, MJK, DMJ), University of California, San \\ Francisco, California
}

Overexpression of KIT protein (CD117), the product of the c-kit gene, has been shown to have important prognostic and therapeutic implications for a number of malignant neoplasms. Previous studies have shown conflicting results regarding the expression of c-kit in malignant mesothelioma. To determine whether malignant mesothelioma expresses KIT, immunohistochemistry and RT-PCR were used to analyze archived tissue from 37 cases of mesothelioma. Although a subset of mesotheliomas demonstrated specific staining with the DAKO anti-KIT antibody, in each case staining was nuclear. We could not detect $\mathrm{c}$-kit mRNA by a sensitive RT-PCR assay, even in cases with strong nuclear staining. Furthermore, a second anti-KIT antibody (CellMarque) only demonstrated staining in a single mesothelioma case and in none of the cases that demonstrated nuclear staining. We conclude that immunoreactivity for KIT in mesothelioma does not represent expression of the c-kit gene and may represent antibody cross-reaction with nuclear proteins. Our results raise doubt about previously reported expression of KIT in mesothelioma and consequently, the applicability of therapeutic agents that target the kinase activity of KIT.

KEY WORDS: Mesothelioma, C-kit, CD117, Immunohistochemistry, STI571.

Mod Pathol 2003;16(8):818-822

Malignant pleural mesothelioma is a rare mesenchyme-derived tumor with a poor prognosis. Despite aggressive multimodal therapy, reported median survival ranges from 7 to 19 months, and long-term survival is rare (1-4). A variety of recep-

Copyright () 2003 by The United States and Canadian Academy of Pathology, Inc.

VOL. 16, NO. 8, P. 818, 2003 Printed in the U.S.A

Date of acceptance: January 22, 2003.

This project was supported by the UCSF Department of Pathology Resident Research Fund.

Address reprint requests to: Patrick A. Treseler, M.D., Ph.D., Department of Pathology, University of California, San Francisco, Box 0506, San Francisco, CA 94143; fax: 415-353-1828; e-mail: ptres@itsa.ucsf.edu.

DOI: 10.1097/01.MP.0000083647.69123.5C tor tyrosine kinases and their ligands have been implicated in the pathogenesis of mesothelioma, including c-met (5), epidermal growth factor receptor $(6,7)$, and platelet-derived growth factor receptor (8). However, few prognostic markers and no effective therapies have been identified to date for mesothelioma.

The c-kit proto-oncogene codes for a receptor tyrosine kinase (KIT, CD117), required for early maturation of hematopoietic lineages as well as germ cells and melanocytes. Expression of c-kit has been detected in a number of malignancies including lymphomas, melanomas, germ cell tumors, gastrointestinal stromal tumors, and others. It is of note that the recent development of targeted therapy that inhibits the kinase activity of KIT is a promising approach to the treatment of KITpositive tumors (9). Little is known about c-kit overexpression in mesothelioma (10). Specifically, the pattern of staining and anti-KIT antibody specificity have not been extensively studied (10). As part of an ongoing search for prognostic and therapeutic markers of mesothelioma, we analyzed retrospectively KIT immunoreactivity in 37 cases of malignant pleural mesothelioma.

\section{MATERIALS AND METHODS}

Thirty-seven patients with biopsy-proven malignant pleural mesothelioma who underwent pleurectomy were identified from the files of the Division of Thoracic Surgery and the Department of Pathology at the University of California, San Francisco. In each case, the diagnosis was confirmed by a combination of clinical, histopathologic, and immunophenotypic methods. Cases were accepted as malignant mesothelioma if the clinical presentation and the tumor histopathology appeared consistent with the diagnosis and the tumor could be shown to express calretinin, but lack expression of CEA, LeuM1, and B72.3. In equivocal cases, electron microscopy was used to confirm the diagnosis.

Immunohistochemical analysis was performed using standard techniques. Briefly, $4-\mu \mathrm{m}$ paraffin- 
embedded sections were heated; deparaffinized; heated in citrate buffer; blocked for endogenous peroxidase, avidin, and biotin; incubated with antibodies (Table 1); washed; and developed using the LSAB kit (DAKO). The antibodies and conditions used in these experiments are detailed in Table 1. Not all cases were stained with both antibodies. Gastrointestinal stromal tumors were used as positive controls for KIT. Slides were scored jointly by two of us (PT and AEH), and staining for KIT was interpreted as positive if $>5 \%$ of tumor cells showed specific staining. Positive cases were stratified as follows:

Level 1: $>5 \%$ but $<10 \%$ positive cells

Level 2: $\geq 10 \%$ positive cells

Level 3: $\geq 50 \%$ positive cells

Level 4: $\geq 90 \%$ positive cells

Total RNA was isolated from freshly resected mesothelioma or seminoma tissue using Trizol, following the manufacturer's instructions (BRL Life Technologies). For RT-PCR, $2 \mu \mathrm{g}$ of total RNA was heated for 3 minutes at $65^{\circ} \mathrm{C}$ and reverse transcribed in the reaction mixture containing $0.5 \mu \mathrm{g}$ of $\mathrm{pd}(\mathrm{N}) 6 \mathrm{ran}-$ dom hexamer; $0.5 \mathrm{~mm}$ of dNTPs; $1.5 \mathrm{~mm}$ of $\mathrm{MgCl}_{2}$; $75 \mathrm{~mm}$ of Tris-HCl, pH 7.5; $10 \mathrm{~mm}$ of DTT; $20 \mathrm{U}$ of RNasin (Promega); and $200 \mathrm{U}$ of Moloney murine leukemia virus reverse transcriptase (Promega) in a final volume of $20 \mu \mathrm{L}$ for 60 minutes at $42^{\circ} \mathrm{C}$. Two microliters of cDNA products were subjected to PCR amplification. Primer sequences were as follows (sense/antisense): c-kit: 5'-GAG TTG GCC CTA GAA GTT AGA-3'/5'-CCT GGAGGT GGA TGC AAG TT-3' (11); L19: 5'-GAAATCGCCAATGCCAACT-3' / 5'-TCTTAGACCTGCGAGCCTCA-3'. PCR was carried out in the GeneAmp PCR system 9700 in a $50-\mu \mathrm{L}$ final reaction containing $0.4 \mathrm{~mm}$ of each primer, $0.2 \mathrm{~mm}$ of dNTPs, $2 \mathrm{~mm}$ of $\mathrm{MgCl}_{2}, 50 \mathrm{~mm}$ of $\mathrm{KCl}$, and $1 \mathrm{U}$ of Taq DNA polymerase (Roche). The amplification profile was denaturation at $94^{\circ} \mathrm{C}$ for 1 minute, annealing at $60^{\circ} \mathrm{C}$ for 30 seconds, and extension at $72^{\circ} \mathrm{C}$ for 1 minute over 35 cycles. PCR products were analyzed by $1 \%$ agarose gel electrophoresis using standard 1-kb ladder molecular markers.

Statistical analysis of variables between groups was performed by the chi square test.

TABLE 1. Antigen Retrieval Methods and Primary Antibodies Used in Immunostaining

\begin{tabular}{|c|c|c|c|c|}
\hline Antibody & Manufacturer & $\begin{array}{l}\text { Antigen } \\
\text { Retrival }\end{array}$ & Dilution & Incubation \\
\hline A-4205 & $\begin{array}{l}\text { DAKO, Carpinteria, } \\
\text { CA }\end{array}$ & $\begin{array}{l}\text { Microwave at } \\
100 \% 12 \mathrm{~min} \text {, } \\
\text { at } 20 \% 10 \\
\min \end{array}$ & $1: 250$ & $25^{\circ} \mathrm{C} 30 \mathrm{~min}$ \\
\hline CMA-767 & $\begin{array}{l}\text { Cell-Marque, Hot } \\
\text { Springs, AR }\end{array}$ & $\begin{array}{l}\text { Microwave at } \\
100 \% 12 \mathrm{~min}, \\
\text { at } 20 \% 10 \\
\min \end{array}$ & Neat & $25^{\circ} \mathrm{C} 30 \mathrm{~min}$ \\
\hline
\end{tabular}

\section{RESULTS}

Patient tumor types and the level of KIT staining are reviewed in Table 2. Histologically, all three tumor types were seen $(40 \%$ mixed epithelioid and sarcomatoid, $46 \%$ pure epithelioid, and $14 \%$ pure sarcomatoid). Using the DAKO antibody, KIT immunoreactivity was observed in 7/37 (19\%) of cases with staining level ranging from 1 to 3 . Unexpectedly, all positive cases demonstrated primarily nuclear staining and only minimal cytoplasmic staining (Fig. 1, A-C). Repeat studies on additional blocks demonstrated the same pattern of staining (not shown), and positive controls consistently demonstrated strong cytoplasmic staining with this antibody (Fig. 1F). Consequently, a second anti-KIT antibody (Cell-Marque) was used to determine whether the above results were antibody specific. As shown in Table 2, only 1 of 31 cases (3\%) demonstrated positive immunoreactivity with the CellMarque antibody, although in this case the staining was membrane and cytoplasmic rather than nu-

TABLE 2. Tumor Histological Subtype and Staining Level

\begin{tabular}{|c|c|c|c|}
\hline \multirow{2}{*}{ Case Number } & \multirow{2}{*}{ Type $^{1}$} & \multicolumn{2}{|c|}{ Staining Level } \\
\hline & & DAKO & Cell-Marque \\
\hline 1 & M & 0 & 0 \\
\hline 2 & $\mathrm{E}$ & 3 & 0 \\
\hline 3 & M & 0 & 0 \\
\hline 4 & E & 3 & 0 \\
\hline 5 & E & 0 & 0 \\
\hline 6 & $\mathrm{M}$ & 0 & 0 \\
\hline 7 & M & 0 & 0 \\
\hline 8 & $\mathrm{M}$ & 0 & 0 \\
\hline 9 & $\mathrm{M}$ & 0 & 0 \\
\hline 10 & M & 0 & 0 \\
\hline 11 & M & 0 & 0 \\
\hline 12 & $\mathrm{E}$ & 0 & 0 \\
\hline 13 & E & 0 & 0 \\
\hline 14 & E & 0 & 0 \\
\hline 15 & E & 0 & 0 \\
\hline 16 & E & 3 & 0 \\
\hline 17 & S & 0 & 2 \\
\hline 18 & E & 0 & 0 \\
\hline 19 & M & 3 & 0 \\
\hline 20 & E & 0 & 0 \\
\hline 21 & E & 0 & 0 \\
\hline 22 & M & 0 & 0 \\
\hline 23 & M & 0 & 0 \\
\hline 24 & $\mathrm{M}$ & 0 & 0 \\
\hline 25 & E & 1 & 0 \\
\hline 26 & E & 1 & 0 \\
\hline 27 & M & 0 & 0 \\
\hline 28 & $\mathrm{E}$ & 0 & 0 \\
\hline 29 & E & 0 & 0 \\
\hline 30 & S & 2 & 0 \\
\hline 31 & E & 0 & 0 \\
\hline 32 & $\mathrm{M}$ & 0 & ND \\
\hline 33 & S & 0 & ND \\
\hline 34 & E & 0 & ND \\
\hline 35 & E & 0 & ND \\
\hline 36 & E & 0 & ND \\
\hline 37 & $\mathrm{M}$ & 0 & ND \\
\hline
\end{tabular}

${ }^{1} \mathrm{E}=$ epithelioid; $\mathrm{S}=$ sarcomatoid; $\mathrm{M}=$ mixed.

${ }^{2} \mathrm{ND}=$ Not done. 
clear (Fig. 1E). This case did not stain with the DAKO antibody (not shown).

No correlation between presence of staining or level of staining and tumor subtype (epithelial, sarcomatoid, or mixed) was observed ( $P>.05$, respectively).

Reverse transcription PCR was used to estimate the abundance of c-kit mRNA in cases with the highest level of staining for which RNA was available (Cases 2 and 4 ) as well as in two cases without detectable immunohistochemical staining (Cases 3 and 13). Fig. 2 demonstrates representative RT-PCR results. Neither immunohistochemically positive nor negative tumors demonstrated the PCR band of the expected size (749 bp). A positive control de-

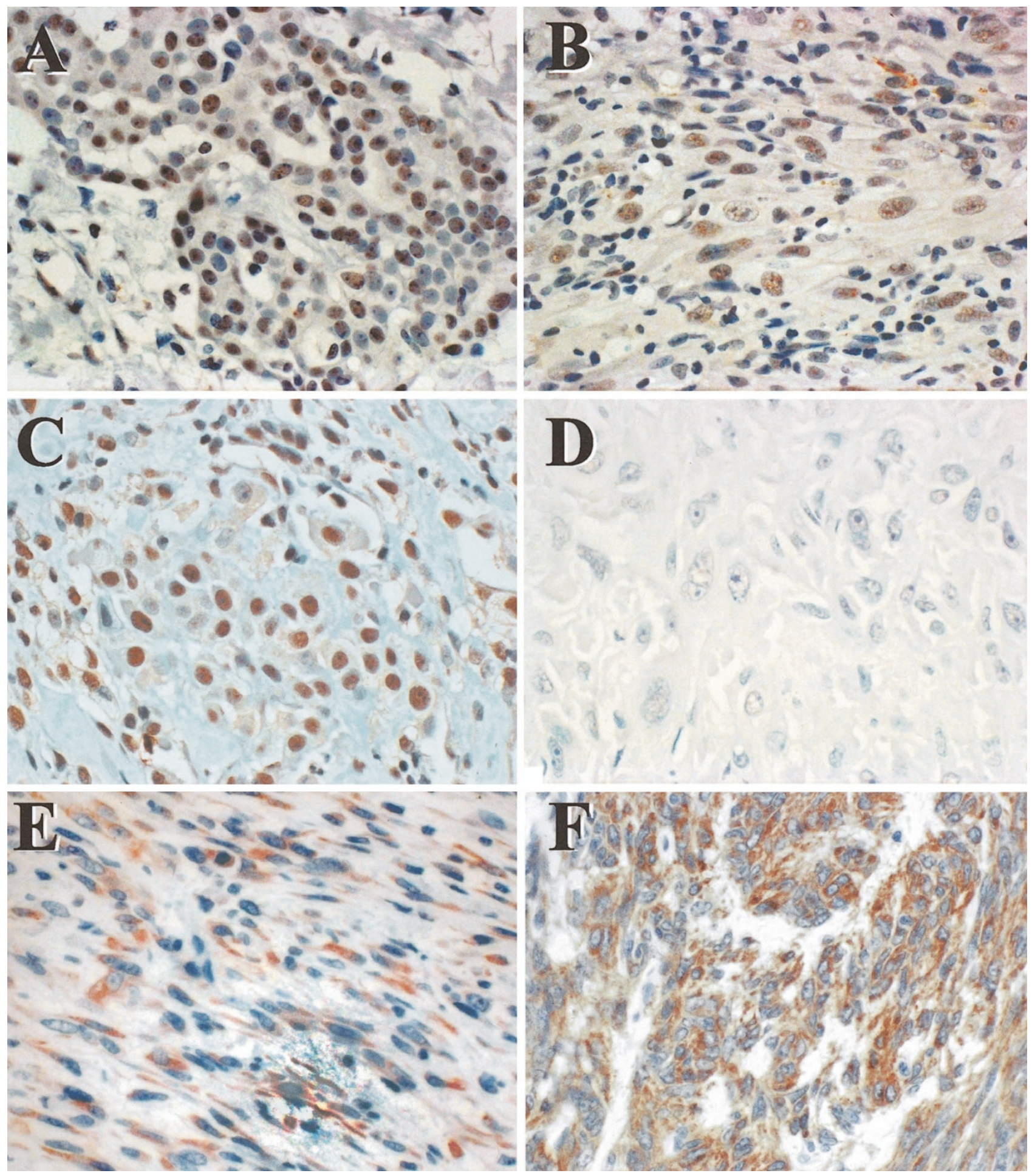

FIGURE 1. Immunoreactivity for c-Kit in malignant mesothelioma. Case 2 (A), Case 4 (B), and Case 16 (C), but not Case 13 (D), demonstrate strong nuclear and weak cytoplasmic immunoreactivity with DAKO antibody. E, cytoplasmic and membrane immunoreactivity with Cell-Marque antibody seen in a single case (Case 17). F, strong cytoplasmic immunoreactivity in a gastrointestinal stromal sarcoma positive control. 


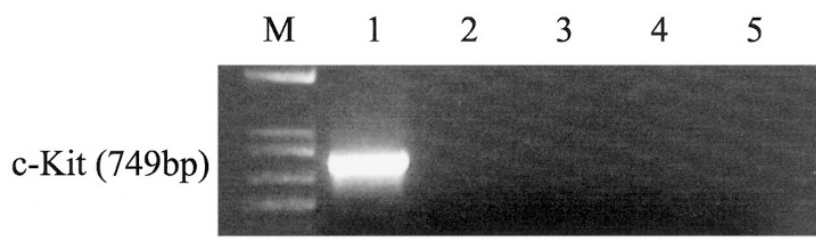

L19 (395bp)

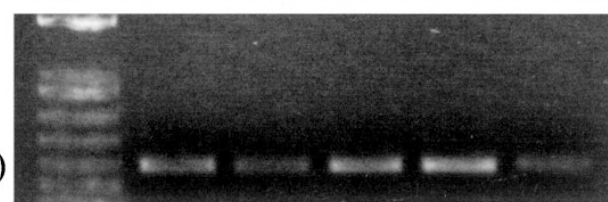

FIGURE 2. RT-PCR analysis. Representative RT-PCR results of c-Kit and ribosomal protein L19 are shown. The detected bands of 749 and 395bp correspond to c-Kit and L19, respectively. M: molecular weight markers. Lane 1: seminoma tissue, Lane 2: Case 2, Lane 3: Case 3, Lane 4: Case 4, Lane 5: Case 13.

rived from seminoma tissue did display amplification of the mRNA for the KIT receptor.

\section{DISCUSSION}

Recent studies have employed paraffin section immunohistochemistry for the evaluation of c-kit overexpression in various malignancies (9). In part, the goal of such screening is to find tumors that may respond to the therapy targeted to inhibit the kinase activity of KIT. This study shows that malignant pleural mesothelioma demonstrates immunoreactivity for KIT but that this reactivity is in only a minority of tumors, demonstrates an unusual nuclear pattern, and does not appear to correlate with transcription of the c-kit gene.

Other studies have shown that mast cells and mast cell tumors demonstrate strong membrane staining (10), whereas gastrointestinal stromal tumors $(12,13)$, seminomas (14-16), and intracranial germ cell tumors (17) demonstrate dense cytoplasmic immunoreactivity. Although the above malignancies are associated with distinct mutations in KIT, each demonstrates expression of KIT at the protein or RNA level. In the current study, using a sensitive RT-PCR assay, even those cases of mesothelioma with the strongest immunostaining using the DAKO antibody failed to show significant c-kit RNA. (Unfortunately, RNA was not available from Case 17, the only sample that demonstrated cytoplasmic staining with the Cell-Marque antibody.)

The precise significance of the unusual nuclear staining pattern seen in mesotheliomas in this study is uncertain. Intriguingly, similar nuclear staining has been observed using anti-KIT antibodies in $40 \%$ of Ewing sarcoma (ES) cases in one series (18). Furthermore, STI571, an agent targeted against the kinase activity of KIT, appeared to inhibit the growth of several ES cell lines. A review of the NCBI protein sequence database reveals that the epitope used to generate the DAKO antibody (C-terminal peptide) shares $64 \%$ sequence identity with a putative DNA binding protein (CAB10847), supporting the possibility of a cross-reaction. On the other hand, the Cell-Marque antibody was also generated against the same C-terminal peptide of KIT but failed to show nuclear staining in the single positive case.

Overall, our results raise significant doubt as to the expression of c-kit in malignant mesothelioma as reported elsewhere (10) and as to the utility of agents designed to inhibit the kinase activity of KIT in mesothelioma. Given that agents have the potential to inhibit Type III receptor kinases other than KIT, their therapeutic potential in the treatment of mesothelioma remains to be determined.

Acknowledgment: We would like to thank Dr. Joseph Rabban for his help with statistical analysis.

\section{REFERENCES}

1. Boutin C, Schlesser M, Frenay C, Astoul P. Malignant pleural mesothelioma. Eur Respir J 1998;12:972-81.

2. Sugarbaker DJ, Flores RM, Jaklitsch MT, Richards WG, Strauss GM, Corson JM, et al. Resection margins, extrapleural nodal status, and cell type determine postoperative longterm survival in trimodality therapy of malignant pleural mesothelioma: results in 183 patients. J Thorac Cardiovasc Surg 1999;117:54-63.

3. Herndon JE, Green MR, Chahinian AP, Corson JM, Suzuki Y, Vogelzang NJ. Factors predictive of survival among 337 patients with mesothelioma treated between 1984 and 1994 by the Cancer and Leukemia Group B. Chest 1998;113:723-31.

4. Huncharek M, Kelsey K, Mark EJ, Muscat J, Choi N, Carey R, et al. Treatment and survival in diffuse malignant pleural mesothelioma; a study of 83 cases from the Massachusetts General Hospital. Anticancer Res 1996;16:1265-8.

5. Tolnay E, Kuhnen C, Wiethege T, Konig JE, Voss B, Muller KM. Hepatocyte growth factor/scatter factor and its receptor c-Met are overexpressed and associated with an increased microvessel density in malignant pleural mesothelioma. J Cancer Res Clin Oncol 1998;124:291-6.

6. Faux SP, Houghton CE, Hubbard A, Patrick G. Increased expression of epidermal growth factor receptor in rat pleural mesothelial cells correlates with carcinogenicity of mineral fibres. Carcinogenesis 2000;21:2275-80.

7. Syrokou A, Tzanakakis GN, Hjerpe A, Karamanos NK. Proteoglycans in human malignant mesothelioma. Stimulation of their synthesis induced by epidermal, insulin and plateletderived growth factors involves receptors with tyrosine kinase activity. Biochimie 1999;81:733-44.

8. Metheny-Barlow LJ, Flynn B, van Gijssel HE, Marrogi A, Gerwin BI. Paradoxical effects of platelet-derived growth factor-A overexpression in malignant mesothelioma. Antiproliferative effects in vitro and tumorigenic stimulation in vivo. Am J Respir Cell Mol Biol 2001;24:694-702.

9. Heinrich MC, Blanke CD, Druker BJ, Corless CL. Inhibition of KIT tyrosine kinase activity: a novel molecular approach to the treatment of KIT-positive malignancies. J Clin Oncol 2002;20:1692-703.

10. Arber DA, Tamayo R, Weiss LM. Paraffin section detection of the c-kit gene product (CD117) in human tissues: value in 
the diagnosis of mast cell disorders. Hum Pathol 1998;28: 498-504.

11. Tamborini E, Papini D, Mezzelani A, Riva C, Azzarelli A, Sozzi G, et al. c-KIT and c-KIT ligand (SCF) in synovial sarcoma (SS): an mRNA expression analysis in 23 cases. Br J Cancer 2001;85:405-11.

12. Lux ML, Rubin BP, Biase TL, Chen CJ, Maclure T, Demetri G, et al. KIT extracellular and kinase domain mutations in gastrointestinal stromal tumors. Am J Pathol 2000;156:791-5.

13. Miettinen M, Lasota J. Gastrointestinal stromal tumorsdefinition, clinical, histological, immunohistochemical, and molecular genetic features and differential diagnosis. Virchows Arch 2001;438:1-12.

14. Tian Q, Frierson HF Jr, Krystal GW, Moskaluk CA. Activating c-kit gene mutations in human germ cell tumors. Am J Pathol 1999;154:1643-7.
15. Bokemeyer C, Kuczyk MA, Dunn T, Serth J, Hartmann K, Jonasson J, et al. Expression of stem-cell factor and its receptor c-kit protein in normal testicular tissue and malignant germ-cell tumours. J Cancer Res Clin Oncol 1996;122: 301-6.

16. Izquierdo MA, Van der Valk P, Van Ark-Otte J, Rubio G, Germa-Lluch JR, Ueda R, et al. Differential expression of the c-kit proto-oncogene in germ cell tumours. J Pathol 1995; 177:253-8.

17. Rabban JT, Zaloudek C. CD117(c-kit) expression specifically distinguishes germinoma among germ cell tumours of the central nervous system (CNS) [abstract]. Mod Pathol 2002; 15:301A.

18. de Alava E, Gonzalez I, Panizo A, Andreu E, Idoate MA, Lozano $\mathrm{MD}$, et al. C-Kit expression in Ewing tumors. A potential therapeutic target [abstract]. Mod Pathol 2002;15:301A. 